\title{
Analisis Makna Character Building pada Perilaku Nabi Muhammad dalam Surat Al-Mukminun [23] ayat 1-11
}

\author{
Muhammad Soleh Ritonga \\ FTIK, UNINDRA PGRI Jakarta, Indonesia \\ email: muhammadsolehrtg@gmail.com
}

\begin{abstract}
Character building must follow the example of the Prophet Muhammad. Because he is the incarnation of the Al-Qur'an, a human being who is successful in his life in the world with the various problems he faces and the several professions he does. Allah gave him success in this world and the hereafter. We can see this in Surah alMukminun verses 1-11. There, the tips for becoming a successful person are explained by implementing the characters implied in these verses. The first character that must be possessed is a religious personality. The second personal character is focused on concentration, praying seriously'. This prayer is like the head of all deeds. If the prayer is good, other deeds will be good, but if the prayer is not good, it will also affect the unworthiness of the other deeds. After prayer there is a character of discipline by keeping away from useless things that are not useful, be it deeds or words. then the character of obedience in paying zakat, shows a sense of social or caring. Then the personal character who is responsible by maintaining self-respect by using the available facilities in a halal way. Furthermore, a personal character that is trustworthy, the importance of maintaining trust and promise is a form of character of a person who can be trusted. And lastly is a consistent character, maintaining prayers regularly and working hard, istiqamah which shows that the person is able to be consistent in maintaining goodness. According to Al-Mâwardiy, carrying out these characters results in success in any field, be it education, economy, profession and so on. Even lasting success will be found in the afterlife.
\end{abstract}

\section{Keywords:}

Tips, Profession, Incarnation, Implementation

\begin{abstract}
Abstrak
Pembentukan karakter harus mencontoh dari tauladan Nabi Muhammad. Karena beliau adalah penjelmaan dari Al-Qur'an, manusia yang sukses dalam kehidupannya di dunia dengan berbagai masalah yang beliau hadapi dan beberapa profesi yang beliau lakukan. Allah berikan kepada beliau kesuksesan dunia dan akhirat. Hal ini bisa kita lihat dalam surat al-Mukminun ayat 1-11. Di situ dijelaskan kiat menjadi orang yang sukses dengan mengimplementasikan karakter-karakter yang tersirat
\end{abstract}


pada ayat-ayat tersebut. Karakter pertama yang harus dimiliki adalah personal yang religius. Karakter kedua personal yang fokus penuh konsentrasi, melaksanakan shalat dengan khusu'. Shalat ini ibarat kepala dari segala amal. Kalau shalat bagus amalamal yang lain akan ikut bagus, tapi kalau shalat tidak bagus akan mempengaruhi pula ketidak bagusan amal-amal yang lain. Setelah shalat ada karakter disiplin dengan menjauhkan diri dari hal-hal yang sia-sia yang tidak bermanfaat, baik itu perbuatan ataupun perkataan. kemudian karakter ketaatan dalam membayar zakat, menunjukkan adanya rasa sosial atau kepedulian. Kemudian karakter personal yang responsibility dengan menjaga kehormatan diri dengan menggunakan fasilitas yang tersedia dengan cara yang halal. Selanjutnya karakter personal yang amanah, pentingnya memelihara amanah dan janji merupakan bentuk karakter orang yang dapat dipercaya. Dan terakhir adalah karakter konsisten, memelihara shalat dengan rutin dan kerja keras, istiqamah yang menunjukkan orang tersebut mampu konsiten dalam menjaga kebaikan. Menurut Al-Mâwardiy dengan melakukan karakterkarakter tersebut menghasilkan kesuksesan dalam bidang apapun, baik itu bidang pendidikan, ekonomi, profesi dan lain sebagainya. Bahkan kesuksesan yang bersifat abadi pun akan didapat di akhirat.

\section{Kata Kunci:}

Kiat, Profesi, Penjelmaan, Implementasi

\section{Pendahuluan}

Pada akhir-akhir ini masalah sosial sangat merisaukan bangsa Indonesia, sosial kehidupan menjadi carut marut. Banyaknya karakter masyarakat yang menyimpang membuat suasana kacau. Tentu berimbas pada out put yang menghasilkan generasigenerasi dan warga negara yang tidak sukses dari berbagai bidang kehidupan. Sebagaimana yang diungkapkan Ketua Yayasan Pendidikan dan Pembina Universitas Pancasila Siswono Yudo Husodo disela-sela acara Sarasehan Nasional Pusat Studi Pancasila Seluruh Indonesia bertajuk Pancasila dan Nasionalisme Era Millenial, di Fakultas Farmasi Universitas Pancasila, Jakarta, Rabu (29/11). Kondisi yang dihadapi saat ini terasa semakin berat lantaran kuatnya arus informasi yang sebagian diantaranya merupakan contoh buruk. Maklum, pendidikan moral dan etika di sekolah juga dinilai masih kurang, apalagi dengan ketiadaan mata pelajaran budi pekerti.

Melihat kondisi sosial masyarat Indonesia saat ini banyaknya timbul keresahan disebabkan akibat perilaku yang tidak terpuji. Hal ini kalau dibiarkan tentu akan 
membawakan dampak yang akan menghancurkan agama dan bangsa. Karakter yang tidak baik akan berdampak kepada hasil yang diperoleh dengan arti kata menjadi orang yang tidak sukses dalam berbagai bidang.

Paripurnanya seorang muslim yang beriman adalah terbentuknya karakter yang baik (akhlak yang mulia) pada dirinya. Tidak bisa dipungkiri agama Islam adalah agama yang yang Allah jadikan untuk memproduksi insan yang berakhlakul karimah. Hal ini dapat kita lihat pada hadits nabi Muhammad saw:

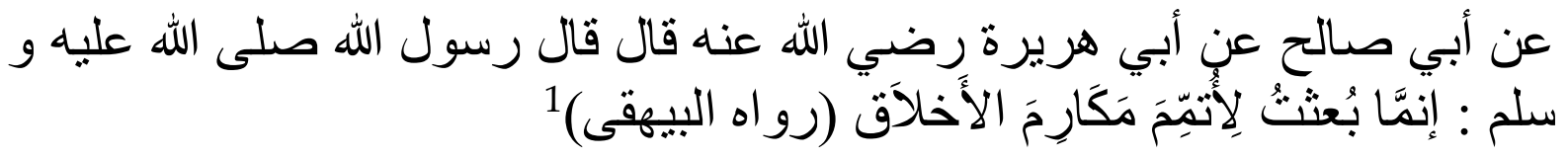

Dari Abi Shalih dari Abi Hurairah r.a beliau berkata, telah bersabda Rasulullah SAW, sesungguhnya aku diutus hanya untuk menyempurnakan akhlak yang mulia. (HR. AlBaihaqi)

Dalam Islam orang yang berakhlak mulia dipandang sebagai manusia yang agung. Parameter keislaman seseorang akan terlihat dari karakternya bukan dari pangkat atau kekayaannya. Karakter (akhlak) ini timbul dari jiwa bukan karena paksaan atau hal lainnya, sebagaimana pendapat imam Ghozâliy:

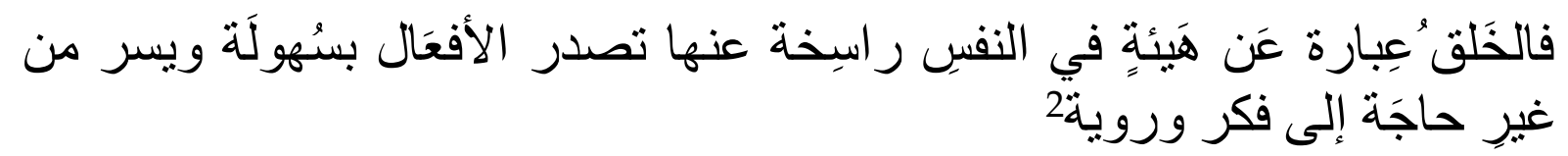

Akhlak adalah sifat yang tertanam dalam jiwa, yang dari padanya timbul perbuatanperbuatan dengan mudah dengan tidak memerlukan pertimbangan pikiran.

Supaya timbul karakter baik dalam jiwa yang membawakan kesuksesan tersebut maka perlu adanya teladan dan rutinitas amaliyah yang harus dilakukan. Tentu teladan bagi kita umat Islam adalah Rasulullah SAW, sedangkan rutinitas amaliyahnya dapat kita lihat pada Al-Qur'an, salah satunya pada surat al-Mukminun ayat 1-11.

\footnotetext{
${ }^{1}$ Ahmad ibn al-Husain ibn 'Aliy ibn Mûsâ Abû Bakr 'Alî al-Baihaqiy, Sunan al-Baihaqiy al-Kubrâ, Makkah al-Mukarramah: Maktabah Dât al-Bâz, juz 10, no. 20571, bab Bayâni Makârima al-Akhlâq, 1414 H/ 1994 M, 191.

${ }^{2}$ Muhammad bin Muhammad Al-Ghozâliy Abû Hâmid, Ihyâ'u Ulûm al-Dîn, Bairût: Dar al-Ma'rifah, t.t, juz 3, 53.
} 


\section{Tinjauan Pustaka}

Kajian seputar karakter dalam surat Al-Mukminun ayat 1-11, bukanlah sebuah kajian baru dalam kajian ilmiah. Telah banyak kajian terdahulu yang membahas topik tersebut. Seperti, Karya HZ, Syarafuddin, yang membahas "Tujuh Karakter Orang Mukmin dalam Surat Al-Mukminun Ayat 1 - 11 (Tinjauan dari Berbagai Macam Kitab Tafsir)," yang diterbitkan pada Jurnal Suhuf. Tulisan ini menjelasakan sifat-sifat orang yang beriman dengan mengkaji berbagai tafsir. ${ }^{3}$ Persaman dengan artikel penulis sama-sama meneliti pada surat dan ayat yang sama. Sedangkan perbedannya HZ, Syarafuddin fokus pada pengkajian penafsiran dari berbagai kitab tafsir. Sedangkan penulis fokus pada kiat mencapai kesuksesan melalui karakter yang tersirat dari surat Al-Mukminun ayat 1-11. Karya lainnya adalah penelitian Mazro'atus Sa'adah, dengan bahasan “Pendidikan Karakter dalam Al-Qur'an (Tafsir QS. Al-Mukminun (23)': 1-11)," diterbitkan pada Jurnal Ilmu Tarbiyah "At-Tajdid," 4 Persaman dengan artikel penulis sama-sama meneliti pada surat dan ayat yang sama. Sedangkan perbedannya Mazro'atus Sa'adah dalam penelitiannnya fokus pada masalah khusus pendidikan karakter sedangkan penulis dalam mengkaji ayat tersebut kiat sukses secara umum. Selanjutnya adalah penelitian yang dilakukan oleh Anas Mohd Yunus, Mohd Rahim Ariffin, Mohd Shafle Hamzah, dengan judul "CiriCiri Motivasi dalam Surah Al-Mukminun Ayat 1-11," diterbitkan pada Jurnal ISLAM dan Masyarakat Kontemporari. Penelitian ini bertujuan untuk menyoroti ayat-ayat Alquran yang signifikan sesuai dengan faktor motivasi modern. Sebagai persaman dengan artikel penulis sama-sama meneliti pada surat dan ayat yang sama. Sedangkan perbedaan, Anas Mohd Yunus dan kawan-kawan fokus meneliti tentang motivasi dari surat Al-Mukminun Ayat 1-11 tersebut. Penulis tidak meneliti isyarat

\footnotetext{
${ }^{3} \mathrm{HZ}$, Syarafuddin, "Tujuh Karakter Orang Mukmin dalam Surat Al-Mukminun Ayat 1 - 11 (Tinjauan dari Berbagai Macam Kitab Tafsir)," Suhuf, 21, no. 1, (Mei 2009): 66-81.

${ }^{4}$ Mazro'atus Sa'adah, dengan bahasan "Pendidikan Karakter dalam Al-Qur'an (Tafsir QS. AlMukminun (23)': 1-11)," Ilmu Tarbiyah “At-Tajdid," 2, no. 1, (Januari 2013):51-67.
} 
motivasi tapi kiat-kiat yang dilakukan dalam mencapai kesuksesan berbagai hal dari beberapa penafsiran para ulama. ${ }^{5}$

\section{Metode Penelitian}

Dalam menulis penelitian ini, menggunakan penelitian bercorak library, dan pendekatan penelitian ini menggunakan pendekatan kualitatif dengan metode Mudhu'i. Sebagai sumber primernya terdiri dari kitab-kitab tafsir, seperti ; Marâh Labîd Tafsîr al-Nawawiy, karya Muhammad Nawawî Al-Jâwiy ; Shafwah al-Tafâsîr, karya Muhammad 'Alî Al-Shâbûnî, dan kitab-kitab tafsir lainnya yang tertera dalam daftar isi. Sedangkan sumber skundernya adalah beberapa buku dan jurnal penunjang dalam penelitian ini. Sedangkan sumber tersier diambil dari website.

\section{Hasil Penelitian dan Pembahasan}

Karakter yang timbul dari Nabi Muhammad adalah gambaran yang dipraktekkan beliau dari Al-Qur'an. Hal tersebut dapat dilihat pada Surat alMukminun ayat 1-11. Surat ini termasuk golongan surat makkiyah terdiri dari 118 ayat menurut ulama Kufah, sedangkan menurut ulama Basrah 119 ayat. Adapun kalimat yang terdapat dalam surat al-Mukminun ini berjumlah 1840 kalimat dan 1800 huruf. ${ }^{6}$

Pada ayat 1-2 dari surat al-Mukminun, berbunyi:

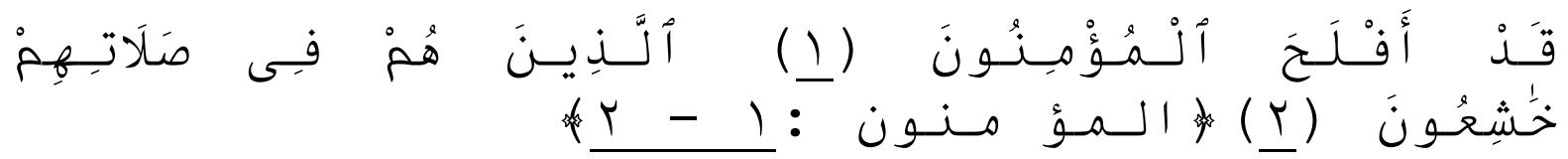

Sungguh beruntung orang-orang yang beriman (1) (Yaitu) orang yang khusyuk dalam salatnya (2) (QS. Al-Mukminun/23 : 1-2)

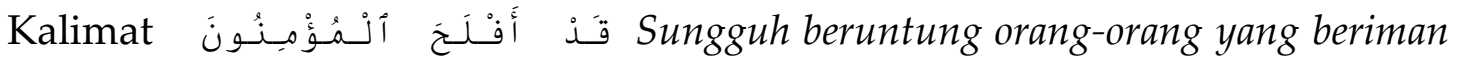
(1) mengandung arti bahwa orang-orang yang beriman merekalah yang mendapat

\footnotetext{
${ }^{5}$ Anas Mohd Yunus Mohd Rahim Ariffin Mohd Shafle Hamzah, "Ciri-ciri Motivasi dalam Surah Ayat 1-11," ISLAM dan Masyarakat Kontemporari, 2, (2009): 147-164.

${ }^{6}$ Muhammad Nawawî Al-Jâwiy, Marâh Labîd Tafsîr al-Nawawiy, Dâr al-Kutub al-Islâmiyyah: Jakarta, t.t, juz 2, 62 .
} 


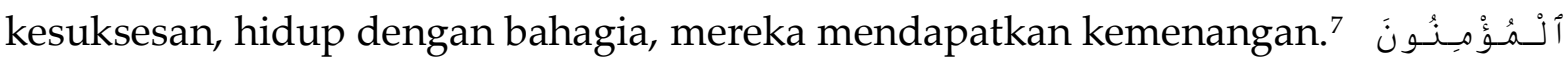
adalah kata jama' yang berarti banyak, termasuk nabi Muhammad, karena jelas Nabi Muhammad adalah seorang mukmin sekaligus imamnya orang-orang mukmin. Dalam tafsir al-Safwah al-Tafâsîr, selain mengandung arti diatas bahwa orang-orang mukmin tersebut mendapatkan tujuan yang mereka harapkan, termasuk juga menjadi tuntunan bagi orang-orang mukmin yang berkarakter dengan karakter yang mulia ini. Pada awal kalimat didhului dengan kata a $_{\text {y }}$ ang tujuannya adalah untuk menguatkan dan membenarkan, dengan perumpamaan seolah-olah dikatakan sungguh benar pencapaian yang mereka dapatkan dan kesuksesan mereka dengan sebab keimanan, perbuatan baik mereka ${ }^{8}$

Dalam tafsir al-Mâwardiy diterangkan bahwa makna kesuskesan pada ayat tersebut terdiri dari tiga makna $:^{9}$

1. Kebahagaiaan orang-orang mukmin

2. Kemenangan yang kekal dengan pengertian sebab amal mereka yang konsisten, bisa juga dikatakan mereka kekal di surga atau melakukan حي yang mempunyai arti mari mengerjakan kebaikan dengan istiqomah atau konsisten

3. Pencapaian yang dicari para pencari sebagai tujuan akhir yang diinginkan Dari pemaparan al-Mâwardiy di atas terlihat jelas, bahwa karakter yang disebutkan pada surat Al-Mukminun ayat 1-11 akan menghasilkan manusia manusia yang sukses dalam bidang apapun, baik itu bidang pendidikan, ekonomi, profesi dan lain sebaginya. Bahkan kesuksesan yang bersifat abadi di akhirat

Dalam mencapai keinginan dan cita-cita dalam bidang apapun di dunia dan kesuksesan di akhirat maka harus melakukan beberapa karakter yang baik

\footnotetext{
${ }^{7}$ Abû al-Fidâ'Ibn Katsir al-Damisqy, Tafsîr al-Qur'ân al-'Azhîm, Bairût: Dâr al-Fikr, 1417 H/ 1997 M, cet. 1, juz 3, 252.

${ }^{8}$ Muhammad 'Alî al-Shabûniy, al-Shafwah al-Tafâsîr, Beirut: Dâr al-Kutub al-Islamiyyah, t.t. jilid 2, 303. ${ }^{9}$ Abû Hasan 'Alî Ibn Muhammad Ibn Habîb Al-Mâwardiy, al-Basriy, al-Nukatu wa al-'uyûn Tafsîr alMâwwardiy, Bairût: Dâr al-Kutub al-'Ilmiyyah. t.t, juz 4, 44-45.
} 
sebagaimana karakter-karakter yang dialakukan Nabi Muhammad tersirat pada surat Al-Mukminun ayat 1-11.

Untuk merealisasikan cita-cita dan harapan kita supaya mendapatkan kesuksesan, bersikap dengan karakter pertama sekali yang harus dimiliki adalah harus personal yang religius, beriman kepada Allah Swt dengan sebenar-benarnya.

Karakter kedua dalam mencapai kesuksesan tersebut dengan melaksanakan apa yang tersirat pada ayat kedua, yaitu:

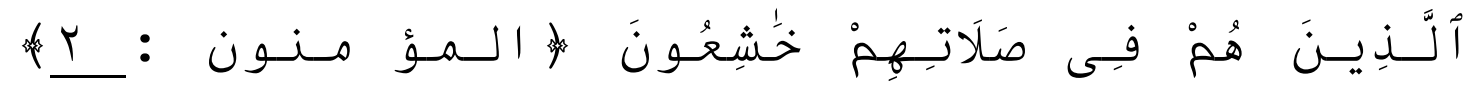
(Yaitu) orang yang khusyuk dalam salatnya (QS. Al-Mukminun/23 : 2)

Karakter di sini adalah fokus, konsentrasi. Jika dilihat dari sebab turunnya ayat ini adalah karena saat shalat Rasulullah menganggkat pandangannya ke langit, maka turunlah ayat ini sebagaimana hadis yang diriwatkan oleh imam Baihaqi:

عن أبي هريرة رضي الله عنه : أن رسول الله صلى الله عليه و سلم كاَن إذَا صَلَّى

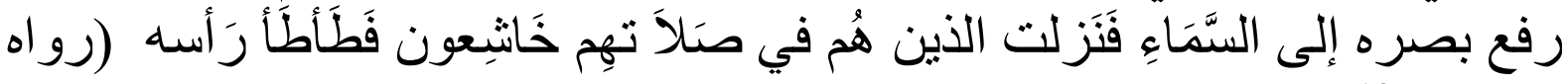
10 البي.مقى )

Dari Abi Hurairah bahwa Raulullah SAW ketika shalat beliau menganggkat penglihatannya ke langit, maka turun ayat الذين هم في صلاتهم خاشعون maka baginda Nabi menundukkan kepalanya (HR. Al-Baihaqi)

Shalat merupakan ibadah yang terpeting dalam Islam karena shalat merupakan amalan yang pertama sekali dihisab pada hari kiamat, sebagaimana sabda Nabi Muhammaad SAW:

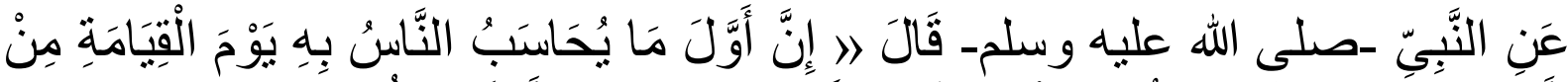

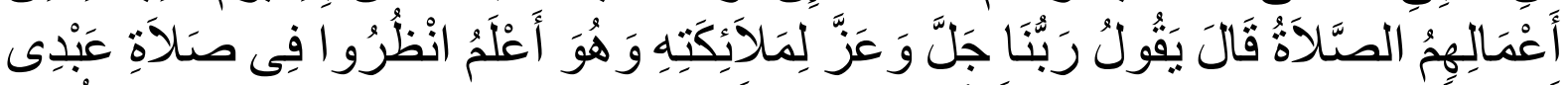

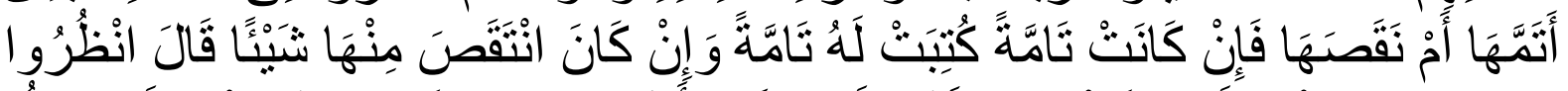

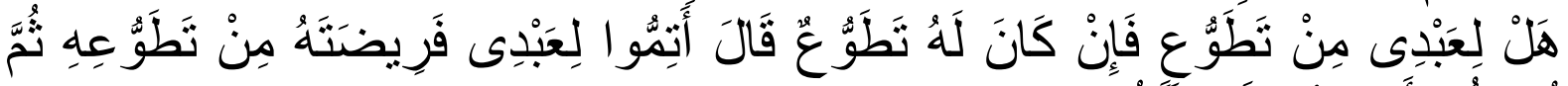

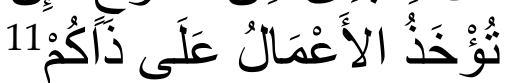

${ }^{10}$ Ahmad ibn al-Husain ibn 'Aliy ibn Mûsâ Abû Bakr 'Alî al-Baihaqiy, op.cit., juz 2, no. 3357, bab Karâhiyah Raf'u al-Bashar ila al-Samâi fi al-Shalâh, 283.

${ }^{11}$ Abû Dâwûd Sulaimân Ibn al-Asy'ats Al-Sajastâniy, op.cit., juz 1, no. 864, bab Qaul al-Nabiy Kullu Shalâtin Lâ Yatimmuhâ Shâhibuhâ Tatimmu min Tathawwi'ih, 322. 
Dari Nabi Muhammad saw beliau bersabda, sesungguhnya pertama sekali yang dihisab pada manusia di hari kiamat dari amal mereka adalah shalat, berkata Tuhan kita Jalla wa Ajja kepada malaikat padahal Allah lebih tahu, kalian (malaikat) lihatlah shalat hambaku ini apakah shalatnya sempurna atau kurang, Allah berfirman: lihatlah wahai malaikat apakah hambaku ini punya shalat sunnah, jika adalah shalt sunnahnya sempurnakanlah shalt fardhunya dari shalat sunnahnya, kemudian diambillah amalamal tersebut untuk keperluan penyempurnaan shalt fardhu tersebut. (HR. Abi Daud)

Begitu pentingnya shalat tersebut sampai sampai amal yang pertama dihisab adalah shalat, karena shalat akan mempengaruhi amal yang lain, shalat akan menciptakan karakter yang baik bagi seorang mukmin. Hal ini dapat kita lihat dalam firman Allah pada surat al-Ankabut/29 ayat 45:

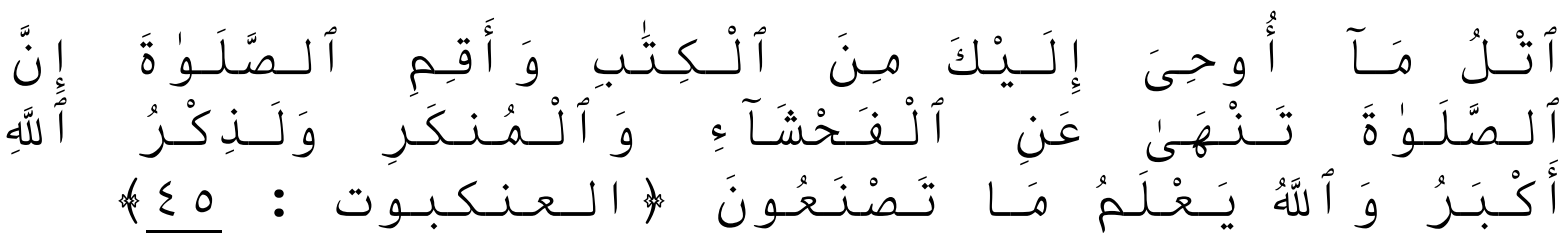

Bacalah Kitab (Al-Qur'an) yang telah diwahyukan kepadamu (Muhammad) dan laksanakanlah salat. Sesungguhnya salat itu mencegah dari (perbuatan) keji dan mungkar. Dan (ketahuilah) mengingat Allah (salat) itu lebih besar (keutamaannya dari ibadah yang lain). Allah mengetahui apa yang kamu kerjakan (QS. Al-'Ankabut/29: 45)

Orang mukmin yang benar dalam melaksanakan shalat dia akan terhindar dari Ta'thil (orang yang mengingkari tentang adanya Allah) dan Isyrak (orang yang menetapkan adanya tuhan selain Allah). Maka awal pelaksanaan shalat bagi hamba yang beriman ia memulainya dengan perkataan الله أكـبـ Perkataan اللهر adalah untuk menafikan ta'thil, sedangkan kata أكـــ untuk menafikan tasyrik karena adanya persekutuan dengan yang lainnya akan membuat ketidak Maha Besar lagi. Ketika

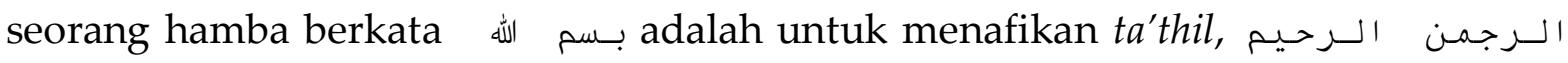
merupakan penafiaan terhadap isyrak, karena الـرجمن adalalah Allah yang memberikan wujud bagi makhluk dan الـرحيم adalah Allah yang memberikan rezki yang kekal. Ketika seorang hamba mengatakan أَنَحَمْدُ لِلَّه sebagai penetapan khilafu al-Ta'thil, sedangkan رَبَّ اَنْعَلَمِيـن sebagai penetapan khilafu al-Isyrak. Ketika kata 
وَ إِيَّاكَ إِيَّاكَ نَعْبُنُـُ merupakan penfian ta'thil dan penafian isyrak, begitu juga merupakan ta'thil dan penafian isyrak juga. Ketika seorang hamba mengatakan أَهـد adalah untuk menfikan ta'thil karena seorang yang meminta jalan tentu dia punya tempat tujuan, sedangkan orang ta'thil tidak punya

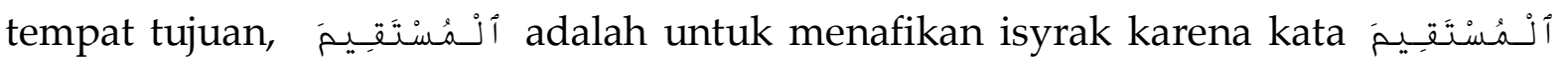
menunjukkan Allah dekat, orang musyrik menyembah berhala-berhala dengan perasangkaan mereka akan mendapat syafaat dari berhala-berhala tersebut. Padahal menyembah Allah tanpa perantara menunjukkan Allah dekat. Seperti inilah sampai

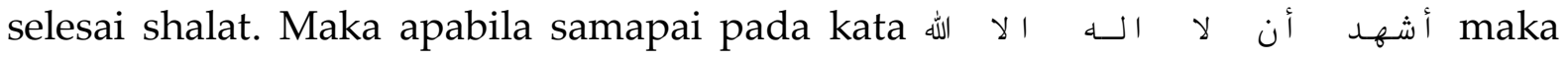
sesungguhnya untuk menafikan isyrak dan ta'thil dengan pengertian shalat mencegah perbuatan keji dan munkar, karena bermunajat kepada Allah mesti munajat itu berbarengan dengan penyempurnaan mengerjakan ketaatan dan melakukan penolakan terhadap semua maksiat. ${ }^{12}$

Mendirikan shalat adalah merealisasikan pelaksanaannya dengan rukunrukun, syarat-syarat dan adab-adab shalat karena shalat adalah tiang agama. Shalat itu dikerjakan dengan segala syarat dan adabnya beserta melengkapinya dengan kekhusu'an dan hukum-hukumnya, mengingat keagungan Allah, memikirkan bacaan maka dia akan tercegah dari perbuatan keji dan munkar. ${ }^{13}$

Menurut Ibnu Abbas khusu' adalah rasa takut dalam keadaan yang tenang. ${ }^{14}$ Ketakutan dalam ketenangan adalah takut hanya kepada Allah. Berbeda takut dalam keadaan tidak tenang, gambaran ini adalah orang yang takut dengan selain Allah atau makhluk-Nya. Untuk mencapai kekhusu' ini perlu ditempuh dengan lima cara :15

1. Ada rasa takut

2. Adanya kepatuhan

3. berharap keampunan dari Allah

\footnotetext{
${ }^{12}$ Muhammad Nawawî Al-Jâwiy, op.cit., juz 2, 158.

13 Muhammad 'Alî al-Shabûniy, op.cit., jilid 2, 462.

${ }^{14}$ Abû al-Fidâ' al-Hafîzh Ibn Katsir al-Damisqy, op.cit., juz 3, 252.

${ }^{15}$ Abû Hasan 'Alî Ibn Muhammad Ibn Habîb Al-Mâwardiy, al-Basriy, op.cit., juz 4, 45-46.
} 
4. Menundukkan penglihatan dan pundak

5. Memandang ke tempat sujud

Maka tempat khusu' dari cara pencapaiannya tersebut terdapat dua pendapat, yaitu:

1. Hanya bertempat dalam hati, ini pendapat Hasan dan Qatadah

2. Hati dan mata, ini pendapat Mujahid dan Ibrahim

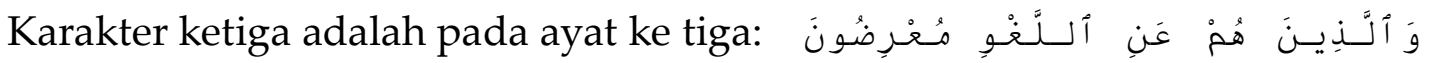
(ㄴ) dan orang yang menjauhkan diri dari (perbuatan dan perkataan) yang tidak berguna (3). Dalam kehidupan sehari-hari pasti manusia akan mengadakan komunikasi atau interaksi, baik secara interpersonal, kelompok maupun massa. ${ }^{16}$ Pola komunikasi dan interaksi tersebut tentu tidak bisa dihindari karena manusia makhluk sosial, berbeda kalau manusia tersebut hidup terpencil dan mengucilkan diri sendiri. Cara manusia berkomunikasi akan sangat menentukan kehidupan dalam dunia sosialnya: kehancuan atau perdamaian, sukses atau gagal. Sebagai makhluk sosial interaksi ini sangat penting dalam keberlangsungan kehidupan seseorang. Dalam Islam seorang mukmin dalam melakukan komunikasi dan interaksinya orang lain harus didasari kecerdasan emosional dan spiritual sehingga apapun yang dikatakan dan diperbuat akan bermanfaat, bagi sesama manusia (habluminannas) dan sampai pada hakikatNya (habluminallah). ${ }^{17}$

Orang-orang yang beriman akan meninggalkan perkataan dan perbuatan yang tidak berguna dalam urusan agama dan dunia dalam segala waktu. ${ }^{18}$ Kesia-siaan itu adalah suatu hal yang bathil yang terkandung di dalamnya kesyirikan, kemaksiatan, perkataan dan perbuatan yang tidak berfaedah. ${ }^{19}$ Kesia-siaan ini mengandung unsur kebohongan, caci maki dan untuk fitnah. ${ }^{20}$

\footnotetext{
${ }^{16}$ Ellys Lestari Pambayun, Communication Quoient dalam Pendekatan Emosional dan Spiritual, Bandung: Rosdakarya, 2012, 293

${ }_{17}$ Topikurohman Bedowi, Kecerdasan Komunikasi Spiritual dalam Upaya Membangun Perdamaian dan Toleransi Beragama, El-Madani: Jurnal Dakwah dan Komunikasi Islam, Vol.1 No.2, 2020

${ }^{18}$ Muhammad Nawawî Al-Jâwiy, op.cit., juz 2, 62.

${ }^{19}$ Abû al-Fidâ’ al-Hafîzh Ibn Katsir al-Damisqiy, op.cit., juz 3, 252.

${ }^{20}$ Muhammad 'Alî al-Shabûniy, op.cit., jilid 2, 303.
} 
Seorang yang beriman dia berusaha keras untuk disiplin dalam menjauhi halhal yang menyiakan seperti menghindari perkataan dan ucapan yang mengandung unsur kebohongan walaupun kebohongannya sedikit. Dia akan mengeluarkan katakata yang enak di dengar tidak membuat orang ynag mendengarnya merasa tersakiti atau terzholimi. Bahakan kalu sudah samapi tingkat tinggi kata-katanya menjadi emas selalu ditunggu orang ucapan yang keluar dari mulut orang yang beriman karena mengandung hikmah. Itulah orang yang beriman selalu menjaga sikapnya tidak melakukan hal-hal yang sia-sia termasuk menjauhkan diri untuk memfitnah orang lain.

Dalam tafsir al-Mawardi sia-sia dijelaskan lebih banyak dari yang di atas yaitu sampai mengandung 5 hal, yaitu: ${ }^{21}$

1. Mengandung hal yang jelek

2. Mengandung kebohongan

3. Mengandung sumpah bohong

4. Mengandung cacian

5. Mengandung kemaksiatan

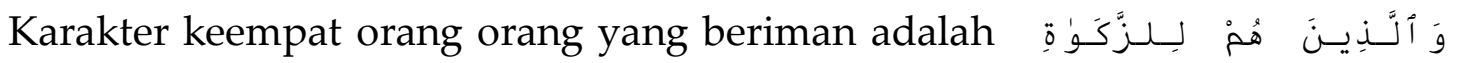

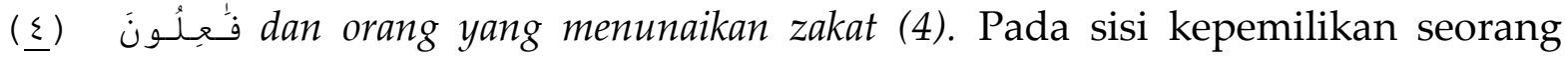
mukmin pun harus punya rasa sosial yang ditunjukannan dengan berbagi dan merupakan suatu hal yang wajib dilaksanakan yaitu dengan membayar zakat.

Membayar zakat ini adalah penunaian zakat dari harta milik sendiri, tentu zakat ini ditujukan kepada yang berhak menerimanya seperti orang-orang fakir dan orang-orang miskin tentu untuk membersihkan jiwa para muzakki dengan niat hanya mencari keridhaan Allah SWT. ${ }^{22}$

Memberikan sebagian harta kepada yang berhak menerimanya merupakan salah satu bentuk rasa sosial yang dilakukan. Dalam dirinya telah tertanam rasa

\footnotetext{
${ }^{21}$ Abû Hasan 'Alî Ibn Muhammad Ibn Habîb Al-Mâwardiy, al-Basriy, op.cit., juz 4, 46.

${ }^{22}$ Muhammad 'Alî al-Shabûniy, op.cit.,.jilid 2, 303.
} 
empati jiwa sosial, ada rasa menyayangi orang yang belum seberuntung dirinya. Zakat ini adalah suatu kewajiban yang harus dilakukan dan memang harus dilakukan tidak bisa tidak. Kalau yang wajib sudah dilaksanakan akan menumbuhkan ibadah sosial yang lain yang bersifat tidak wajib atau disarankan.

Karakter kelima orang beriman yang harus diimplementasikan adalah:

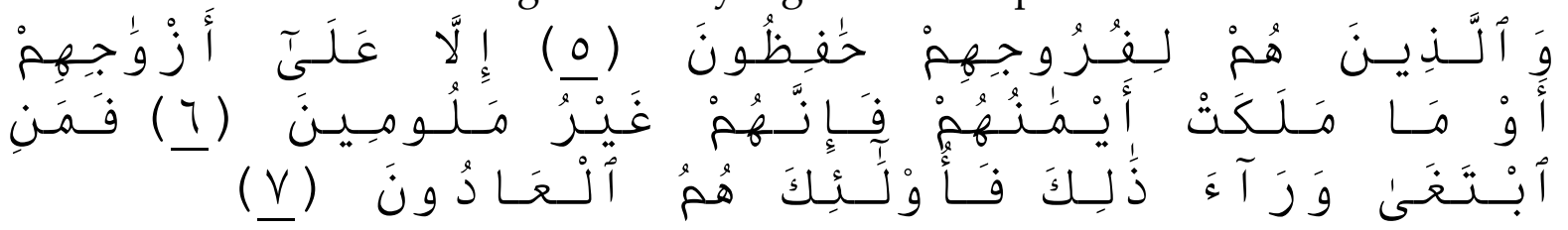

Dan orang yang memelihara kemaluannya (5) Kecuali terhadap istri-istri mereka atau hamba sahaya yang mereka miliki; maka sesungguhnya mereka tidak tercela (6) Tetapi barang siapa mencari di balik itu (zina, dan sebagainya), maka mereka itulah orangorang yang melampaui batas (7)

Pentingnya menjaga kesucian diri dari hal yang diharamkan dalam agama dan mengikuti aturan yang diperbolehkan agama. Islam sangat menghormati kesucian diri sesorang sehingga ada aturan untuk dapat menjalin hubungan suami istri antara laki-laki dengan perempuan yaitu melaui nikah yang sah.

Orang-orang yang memelihara kehormatannya dari hal yang haram, maka mereka tidak terperosok dalam larangan Allah dari zina dan liwath, mereka hanya mendekati istri istri yang sudah halal bagi mereka atau budak-budak mereka. ${ }^{23}$

Ini adalah suatu karakter yang tidak mudah untuk melaksanakannya butuh kesabaran dan keimanan yang tinggi dengan penuh rasa tanggung jawab. Dalam kehiupan sehari-hari harus kita tanamkan dalam jiwa keimanan kepada Allah. Sekarang LGBT lagi marak di Indonesia, ini adalah tugas kita bersama. Pemerintah dengan rakayat harus sam-sama peduli tentang hal ini, karena akan menghancurkan pra generasi bangsa. Kalau generasi bangsa sudah hancur naka negara kita pun dalam bahaya yang luar biasa.

${ }^{23} \mathrm{Abû}$ al-Fidâ’ al-Hafîzh Ibn Katsir al-Damisqiy, op.cit., juz 3, 252. 
Orang yang beriman sangat menjaga kehormatanya, sehingga hanya mau melakukannya dengan cara-cara yang benar yaitu hubungan kepada istri yang sah dan budak mereka yang tidak melanggar aturan dan tidak mendapat sanksi. ${ }^{24}$

Orang beriman akan melakukan hal-hal yang sesuai dengan aturan yang sah dengan cara halal, atau menggunakan fasilitas-fasilitas yang tersedia yang sah menurut hukum dan tidak melanggar aturan hukum.

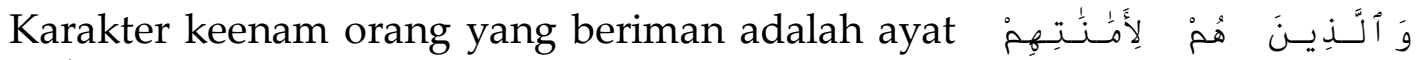

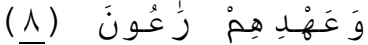

Dan (sungguh beruntung) orang yang memelihara amanat-amanat dan janjinya (8). Orang yang melaksanakan amanah dan janji dengan adanya sikap memelihara dan bersikap baik dari pribadinya, maka setiap perkara yang memebuat meninggalkan amanah dan perjanjian maka dia sudah dikategorikan orang yang berkhianat. Maka amanah dan perjanjian adalah suatu hal yang menjadi pengikat dalam dirinya untuk mendekatkan dirinya pada Allah dan apa yang diperintahkan Allah SWT seperti halnya wudu', mandi jinabah, shalat, puasa, titipan, rahasia dan sebaginya. ${ }^{25}$

Merekalah orang mukmin yang memelihara amanah baik secara pribadi atau secara bersama, memelihara perjanjian baik itu perjanjian yang terjadi dikalangan sesama mereka atau pun perjanjian yang terjadi antara mereka dengan Allah. ${ }^{26}$

Imam Ali al-Shabuni mengutip pendapat Abu Hayyan dalam kitab al-Bahri alMuhith yang mengatakan bahwa zhahir ayat menunjukkan amanah tersebut bersifat umum, maka amanah tersebut bisa masuk amanah yang diberikan Allah kepada hamba-Nya yang berupa perkataan, perbuatan dan aqidah. Dan bisa juga amanah yang diberikan manusia kepada manusia yang lain berupa titipan dan berbagai amanah lainnya. ${ }^{27}$

\footnotetext{
${ }^{24}$ Muhammad 'Alî al-Shabûniy, op.cit.,.jilid 2, 303.

${ }^{25}$ Muhammad Nawawî Al-Jâwiy, op.cit., juz 2, 62.

26Jalâl al-Dîin Muhammad ibn Ahmad Al-Mahallî dan Jalâl al-Dîin Abd al-Rahmân ibn Abî Bakr alSuyûthî, Tafsîr al-Jalâlain, Qâhirah : Dâr al-Hadîs. t.t, 446.

${ }^{27}$ Muhammad 'Alî al-Shabûniy, op.cit., jilid 2, 303.
} 
Jika diberikan amanah kepada mereka mereka tidak khianat bahkan menunaikan amanah tersebut kepada ahlinya. Apabila mereka mengadakan perjanjian mereka memenuhinya tidak seperti sifat orang-orang munafiq yang dijelaskan Raulullah dalam sabdanya:

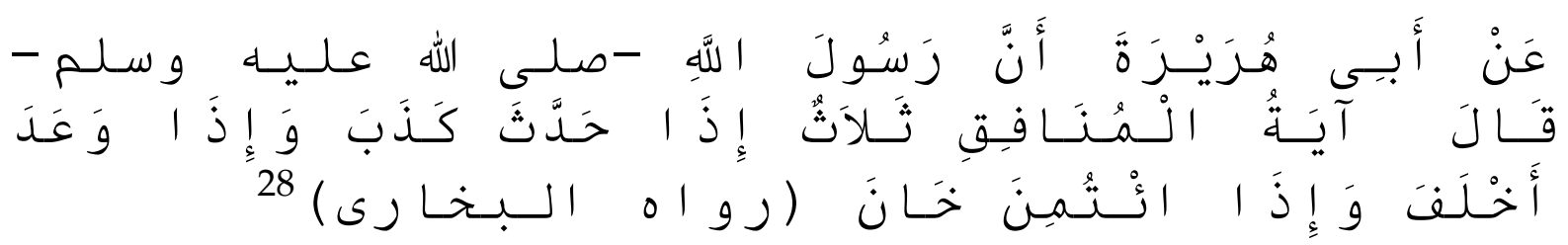

Dari Abi Hurairah bahwasanya Rasulullah SAW bersabda : tanda orang munafiq itu ada tiga, apabila berbicara ia berbohong, apabila berjanji ia menyalahinya dan apabila dipercaya ia berkhianat (HR. Al-Bukhari)

Ketiga tanda di atas merupakan karakteristik dari orang-orang munafiq, maka seorang mukmin tidak akan melakukannya dan dia akan menunaikan amanah dan janji yang diberikan kepadanya.

Amanah adalah hal yang wajib dilaksakan dan dijaga, sekecil apaun amanah yang diberikan kepada seorang mukmin, ia akan menjaga amanah itu dengan sebenar-benarnya. Amanah berhubungan dengan janji karena seorang ketika diserahkan amanah berarti ia sudah memebuat perjanjian untuk melaksanakannya dengan sebaik-baiknya, tidak menyalahi janjinya. Orang tersebut dikategorikan orang yang jujur.

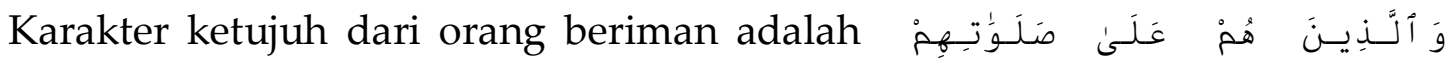
(9) (يُحَا فِظظُونَ serta orang yang memelihara salatnya (9). Mereka memelihara shalat baik secara sendiri atau berjamaah dalam artian mereka melaksanakannya pada

${ }^{28}$ Muhammad ibn Ismâ'îl Abû Abdillah al-Bukhâriy al-Ja'fiy, al-Jâmi' al-Shahîh al-Mukhtashar, Bairût: Dâr Ibnu Katsîr al-Yamâmah, 1407 H/ 1987 M, cet. 3, juz 5, no. hadits 5744, bab 'Alâmat al-Munâfiq; 2262; Abu al-Husain Muslim ibn Al-Hajjâj ibn Muslim Al-Qusyairiy Al-Naisâbûriy, Shahîh Muslim, Bairût: Dâr al-Jail, t.t, juz 1, no. hadits 220, bab Bayâni Khishâl al-Munâfiq, 56; Ahmad ibn al-Husain ibn 'Aliy ibn Mûsâ Abû Bakr 'Alî al-Baihaqiy, op.cit., juz 6, no. hadits 11240, bab Mâ Jâa fî Iqrâr al-Marîdh li Wâritsih, 85; Ahmad ibn Syu' aib Abû Abdillâh al-Rahmân al-Nisâi, al-Sunan al-Kubrâ al-Nisâi, Bairût: Dâr al-Kutub al-'Ilmiyyah, 1411 H/ 1991 M, juz 6, no hadits 11752, bab 'Alâmat al-Munâfiq, 535; Muhammad ibn 'Îsâ Abû 'Îsâ al-Turmudziy al-Sulamiy, al-Jâmi' al-Shahîh Sunan al-Turmudziy, Bairût: Dâr Ihyâ' al-Turâts al-'Arabiy, t.t, juz 5, no hadits 2631, bab Alâmat al-Munâfiq, 19; Ahmad ibn Hanbal Abû Abdillâh al-Syaibâniy, op.cit., juz 2, no hadits 8670, bab Musnad Abî Hurairah Radhiyallâhu 'anh, 357. 
waktunya. ${ }^{29}$ Bukan saja mereka menunaikannya pada watunya tapi mereka selalu menekuni shalat lima waktu tersebut. ${ }^{30}$ Imam Nawawi menambahkan selain yang di atas memelihara syarat-syarat shalat, rukun-rukunnya, thaharah dan selainnya. ${ }^{31}$

Memelihara shalat adalah usaha yang tidak mudah untuk dilakukan karena dia sudah benar-benar melakukan shalat dengan baik dan benar. Ini memerlukan proses, sehingga ketika dalam melaksanakan shalat tidak ada rasa berat tersirat dalam hatinya. Memelihara shalat berarti malaksanakan persyaratan-persyaratan sebelumnya, pengerjaan yang benar saat shalat dan setelah shalat. Sehingga setelah selesai mengerjakan shalat hatinya tetap dalam keadaan shalat dimana pun dia berada. Segala aktifitasnya sudah mencerminkan shalat yang ia laksanakan.

Dalam proses tersebut tergambar seorang mukmin terlatih dengan konsistensasi seorang mukmin dengan usaha kerja keras, giat, ulet, rutin, tidak putus harapan atau tidak mudah putus asa.

Melihat karakter-karakter di atas, pantaslah Allah memberikan balasan berhak mendapat balasan surga jannatil firdaus, sebagaimana firman Allah SWT:

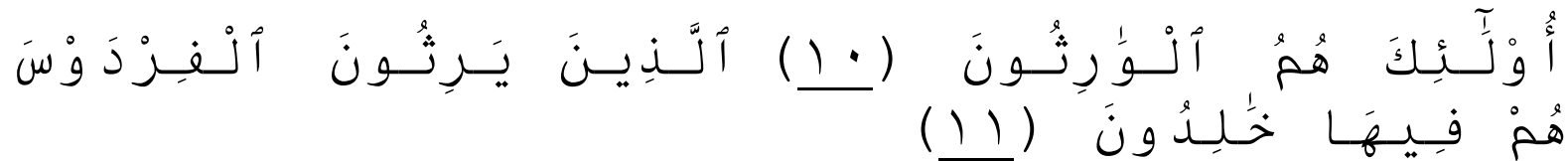

Mereka itulah orang yang akan mewarisi (10) (Yakni) yang akan mewarisi (surga) Firdaus. Mereka kekal di dalamnya (11)

Selain karirnya sukses di dunia, kesuksesan karir orang yang beriman akan berlanjut pada akhirat nanti, yaitu berhak mendapatkan ganjaran surga firdaus. Surga firdaus tersebut merupakan surga yang paling tinggi dari surga yang lainnya. ${ }^{32}$ Tentu kenikmatannya pun paling nikmat dari surga yang lainnya. Kenikmatan yang tidak bisa terbanyangkan dan belum dirasakan sebelumnya, kenikmatan yang belum

\footnotetext{
29Jalâl al-Dîin Muhammad ibn Ahmad Al-Mahallî dan Jalâl al-Dîin Abd al-Rahmân ibn Abî Bakr alSuyûthî, op.cit., 446.

${ }^{30}$ Muhammad 'Alî al-Shabûniy, op.cit., jilid 2, 303-304.

${ }^{31}$ Muhammad Nawawî Al-Jâwiy, op.cit., juz 2, 62.

32Jalâl al-Dîin Muhammad ibn Ahmad Al-Mahallî dan Jalâl al-Dîin Abd al-Rahmân ibn Abî Bakr alSuyûthî, op.cit., 446.
} 
pernah sama sekali dilihat sebelumnya. Kenikmatan yang tidak semu bukan kenikmatan hayalan, tapi kenikmatan yang sempurna yang merupakan pemberian yang Allah berikan kepada mereka yang beriman.

Di dalam surga firdaus tersebut mereka tidak akan menjumpai kematian dan tidak akan pernah mati. Selain itu mereka juga tidak akan pernah dikeluarkan dari surga tersebut. ${ }^{33}$

\section{Kesimpulan}

Kesuksesan yang abadi dan bukan semu adalah kesuksesan yang membawakan seorang bahagia dunia dan akhirat dengan kata lain sudah mendapat ridha Allah SWT. Dalam mencapai kesuksesan tersebut tentu seorang harus membentuk karakternya dengan karakter orang yang beriman dengan mencontoh karakter yang Nabi Muhammad contohkan. Dalam kehidupannya Nabi Muhammad adalah manusia yang sukses dalam segi kehidupannya, seperti kesuksesan beliau mengembala kambing, berdagang, menyatukan umat, menjadi hakim dalam penyelesaian masalah, menjadi panglima perang, kepala negara dan sebagai nabi dan Rasul. Hal tersebut karena nabi berkarakter dengan karakter Al-Qur'an, begitu juga kesuksesan dan nabi di akhirat nanti, sebagaimana yang tergambar dalam surat alMukminun ayat 1-11, yang terdiri:

1. Karakter personal yang religius, percaya kepada Allah SWT

2. Karakter fokus, khusu' dalam shalat

3. Karakter disiplin, tidak melakukan hal yang sia-sia

4. Karakter social spirit, ketaatan membayar zakat

5. Karakter responsibility, menjaga kehormatan diri

6. karakter maintain trust, dengan melaksanakan amanah dan janji

7. karakter konsisten, memelihara shalat

\footnotetext{
${ }^{33}$ Muhammad Nawawî Al-Jâwiy, op.cit., juz 2, 62.
} 


\section{Saran}

Penelitian ini diharapkan memberikan inspirasi bagi para intelektual muslim, untuk lebih banyak melakukan kajian terhadap Al-Qur'an dalam menyelesaikan berbagai masalah kehidupan sosial.

\section{Daftar Pustaka}

Al-Baihaqiy Ahmad ibn al-Husain ibn 'Aliy ibn Mûsâ Abû Bakr 'Alî, Sunan al-Baihaqiy al-Kubrâ, Makkah al-Mukarramah : Maktabah Dât al-Bâz, 1414 H/ 1994 M.

Al-Damisqy, Abû al-Fidâ' al-Hafîzh Ibn Katsir, Tafsîr al-Qur'ân al-'Azhîm, Bairût: Dâr al-Fikr, 1417 H/ 1997 M, cet. 1 .

Al-Ghozâliy, Muhammad bin Muhammad Abû Hâmid, Ihyâ'u Ulûm al-Dîn, Bairût: Dar al-Ma'rifah, t.t.

Al-Ja'fiy, Muhammad ibn Ismâ'îl Abû Abdillah al-Bukhâriy, al-Jâmi' al-Shahîh alMukhtashar, Bairût: Dâr Ibnu Katsîr al-Yamâmah, 1407 H/ 1987 M, cet. 3.

Al-Jâwiy, Muhammad Nawawî, Marâh Labîd Tafsîr al-Nawawiy, Jakarta: Dâr al-Kutub al-Islâmiyyah, t.t.

Al-Mâwardiy, Abû Hasan 'Alî Ibn Muhammad Ibn Habîb, al-Basriy, al-Nukatu wa al'uŷ̂n Tafsîr al-Mâwardiy, Bairût : Dâr al-Kutub al-'Ilmiyyah. t.t.

Al-Naisâbûriy, Abu al-Husain Muslim ibn Al-Hajjâj ibn Muslim Al-Qusyairiy, Shahîh Muslim, Bairût : Dâr al-Jail, t.t.

Al-Nisâi, Ahmad ibn Syu'aib Abû Abdillâh al-Rahmân, al-Sunan al-Kubrâ al-Nisâi, Bairût : Dâr al-Kutub al-'Ilmiyyah, 1411 H/ 1991 M.

Al-Shabuni, Muhammad 'Ali, al-Shafwah al-Tafâsîr, Beirut : Dâr al-Kutub alIslamiyyah, t.t.

Al-Sulamiy, Muhammad ibn 'Îsâ Abû 'Îsâ al-Turmudziy, al-Jâmi' al-Shahîh Sunan alTurmudziy, Bairût : Dâr Ihyâ' al-Turâts al-'Arabiy, t.t. 
Al-Suyûthî, Jalâl al-Dîin Abd al-Rahmân ibn Abî Bakr dan Jalâl al-Dîin Muhammad ibn Ahmad Al-Mahallî, et al, Tafsîr al-Jalâlain-al-Mahallî wa al-Suŷuthî, Qâhirah : Dâr al-Hadîs. t.t.

Bedowi, Topikurohman, "Kecerdasan Komunikasi Spiritual dalam Upaya Membangun Perdamaian dan Toleransi Beragama", El-Madani: Jurnal Dakwah dan Komunikasi Islam, Vol.1 No.2, 2020Departemen Agama RI, Al-Qur'an dan Terjemahannya, $1425 \mathrm{H} / 2004 \mathrm{M}$

Mohd Yunus, Anas, Mohd Rahim Ariffin, dan Mohd Shafle Hamzah, "Ciri-ciri Motivasi dalam Surah Ayat 1-11," ISLAM dan Masyarakat Kontemporari, 2, (2009):

Pambayun, Ellys Lestari , Communication Quoient dalam Pendekatan Emosional dan Spiritual, Bandung: Rosdakarya, 2012, 293

Sa'adah, Mazro'atus, “Pendidikan Karakter dalam Al-Qur'an (Tafsir QS. AlMukminun (23)': 1-11)," Ilmu Tarbiyah “At-Tajdid," 2, no. 1, (Januari 2013):

Syarafuddin, HZ, “Tujuh Karakter Orang Mukmin dalam Surat Al-Mukminun Ayat 1 -11 (Tinjauan dari Berbagai Macam Kitab Tafsir)," Suhuf, 21, no. 1, (Mei 2009): 66-81. 